\title{
THE EFFECT OF ANTIOXIDANTS ON PREVENTING THE RETAINED PLACENTA IN DAIRY COWS
}

\author{
M. Joksimović Todorović, V. Davidović \\ University of Belgrade, Faculty of Agriculture, Nemanjina 6, 11080, Belgrade-Zemun, Serbia \\ Corresponding author: miratodo@agrif.bg.ac.rs \\ Review paper
}

\begin{abstract}
Retaining of placenta is one of the most common ailments in dairy cows and it occurrs if placenta is not removed in the period of 12-14 hour after calving. The ailment is of multifactorial etiology and a primary cause is often unknown. During periparturient period in cows the metabolical, hormonal and biochemical changes are observed. Immunosuppression also characterizes this period and it is associated with endocrinal changes and decreased feed intake. Reduced function of neutrophiles before parturition is in correlation with increased frequency of incidence of postparturition ailments. Selenium and vitamin $\mathrm{E}$ are the most important antioxidants which have a positive effect on neutrophiles function protecting them from oxidative damage.
\end{abstract}

Key words: dairy cows, placenta retaining, selenium, vitamin E

\section{Introduction}

Frequency of retained placenta (RP) in cows after calving is 4-18\% (Han and Kim, 2005). Aetiology of this ailment is not completely confirmed but numerous factors are included: mechanical, nutritive, inadequate management and infectious diseases (Gunay et al., 2011). Some studies show that $30-50 \%$ dairy cows have some metabolical and infectious diseases in the period about parturition. Certain physiological changes that happen during a transitional period may affect a nutritive status and contribute to higher sensitivity to some ailments. In this period the needs for energy are increased and they are caused by the beginning of lactation and insufficient feed intake, what brings the individual into the state of negative energy balance (NEB). The consequences of negative energy balance are mobilisation of fat from body reserves and entering of non-esterified fatty acids (NEFA) into blood. Abundant fat mobilisation and excessive accumulation of NEFA leads to the occurrence of metabolical and inflammatory ailments. Negative energy balance may occur at the end of gestation (Brydl et al., 2008) and contribute to the development of ailments such as fat liver and ketosis (Bertics et al., 1992) or provoke immunosuppression (Goff, 2003). 
Disturbances in energy balance and acidobased balance are key factors for the incidence of placenta retaining. Increased levels of NEFA and ketonuria observed two weeks before parturition are important indicators for possible occurrence of this ailment. Besides these factors an excessive weight of animal must not be neglected (Hayirli et al., 2002) along with numerous management oversights uncomfortable conditions (Grummer et al., 2004) and heat stress (De Rensis and Scaramuzzi, 2003). Oxidative stress may also contribute to placenta retaining. A great number of studies show that addequate supplement of selenium, zinc, cooper, iron and vitamins $\mathrm{A}, \mathrm{C}$ and $\mathrm{E}$ playing a role of antioxidant, can reduce the percent of individuals with retained placenta.

\section{Hormonal and biochemical changes in cows with retained placenta}

Biochemical, hormonal and electrolyte profiles can be used as prognosis criteria for the incidence of placenta retaining in dairy cows. In cows with retained placenta a substantially higher level of progesterone and cortisol, and low level of estrogene is observed in relation to healthy cows (Kornmatitsuk et al., 2000). The increased level of cortisol is associated with the stress in dairy cows. The process of liberation between cotyledons and caruncule depends on hystological changes that happen inside them. In cows with retained placenta the chemotactic activity and leukocytes migration are reduced. On the contrary, increased hemotactic activity and number of lekocytes in placenta enable the proces of ejection of placenta so that in such cases the percent of placenta retaining in cows is low (about 1.4\%). Cortisol reduces the function of neutrophiles and it can completely prevent their activity and thus lead to development of retained placenta. Increased content of cytotoxical aldehyde (malonil aldehyde) in erythrocytes and increased concentration of cortisol are deemed as major indicators of the incidence of retaining placenta. Decreased activity of mieloperoxidasis in cotyledones indicates to a reduced function of neutrophiles while a high activity of lysosomes and acid phosphatasis in retained placenta indicate to an acute inflammatory reaction of fetomaternal combination (Gupta et al., 2005). It is believed that in the week prior parturition the level of estradiol reaches its maximum what helps uterus to get free from the remains of fetal membrane and thus prevent the incidence of endometritis. However, reduced level of estrogene is one of the main factors which increases the risk of the occurrence of retained placenta.

In individuals with this ailment the occurrence of fat liver has also been found. As a consequence thereof, increased concentration of some enzymes in blood (alkaline phosphatase - ALP, aspartate aminotransferase - AST and gamma-glutamyl transferase - GGT) (Semacan and Sevinc, 2005) has been observed as well. Infiltration of fat in the liver is associated with the increase in the level of liver 
enzymes and the fall in the level of glucosis, total lpids, cholesterol, triglycerides and electrolytes in the serum of dairy cows. A fat liver leads to its disfunction with no distruction to hepatocytes and the consequence is the increase in the activity of the liver enzymes (Bülent et al., 2006). In cows with retained placenta it can be combined with accumulation of lipids in hepatocytes. Liberated endotoxines in infectious diseases, such as endometritis, may cause the destruction and necrosis of liver what results in different level of its disfunction (Semacan and Sevinc, 2005). In preparturition cows a hypoglycemia has been observed what was caused by an increased needs of fetus and production of colostrum. Hypoglycemia can be also correlated with a high level of cortisol which is connected with the incidence of placenta retention. It has been determined that hypoglycemia in the last month of gravidity is one of the important indicators of the incidence of retained placenta and metritis (Markiewicz et al., 2001). A total level of lipids, cholesterol and triglyceride in serum is lower in cows with RP than in healthy ones. A low level of cholesterole is a consequence of the increased synthesis of progesterone. The fall in total lipids and triglycerides is in correlation with disturbances in the metabolism of lipids and/or increase in the level of tissual lipolytical enzymes (Michal et al., 2006). Disturbances in energy balance and acid-based balance are key factors for the incidence of RP. Dairy cows, during a longer time period, become adapted to the state in energy balance by way of physiological, metabolic and endocrine changes (Ingvartsen, 2006). This process of adaptation can be monitored by help of indicators such as NEFA, hormonal status and net acido-based excretion (Jorritsma et al., 2003). Due to reduced feed intake in periparturition period there occurs an excessive mobilisation of fat and releasing of NEFA from fat tissue. Metabolism of NEFA in liver is followed by a partial oxidation and creation of ketone bodies or reesterification into triglycerides (lipogenesis). Accumulation of ketone bodies in blood unables the maintaining of homeostasis glucosis. These alternations change the functions of immuno cells, what results in higher frequency of the incidence of RP. The level of proteins in the serum of cows with RP is mostly unchanged but hiperglobulinemia may occur as a consequence of bacterial infection.

The cows with RP are anaemic, the number of erythrocytes concentration of hemoglobine and the percent of hematocrit are significantly reduced. In addition, the leukocytosis associated with lymphopenia and monocytosis is observed.

\section{Immunosuppression and postparturition ailments}

Metabolical and infectious diseases during periparturition period are caused by diminished immuno function in cows (Sharma et al., 2011). Immunosuppression is a consequence of endocrine changes which may happen in this period and reduced feed intake. Insufficient intake of nutritive matters and 
reduced level of vitamina $\mathrm{E}$ are one of many factors which lead to the fall in the activity of neutrophiles, a therefore to their possibility to take active part in the phagocytosis process. Vitamin $\mathrm{E}$ and selenium are the most important antioxidants which enhance the activity neutrophyles protecting them from oxidative damage after intracellular killing of bacteria (Joksimović Todorović and Davidović, 2013). In postparturition period the response of lymphocytes to stimulation by mitogens is reduced as well as the synthesis of antibodies and production of cytokines by immuno cells.

Reduced function of neutrophiles before parturition increases the bovine sensitivity to various postparturition diseases. Neutrophiles are found in greatest number at places with high concentration of interleukine-8 (IL-8) (Elliott et al., 2000). This interleukin is a strong hemoattractant and the activator of neutrophiles. IL-8 secreted by cotyledon and/or uterus enters systemic circulation, attracts neutrophiles and set them to action. It is known that it increases the secretion of colagenasis which accelerates separating of fetal cotyledons from materinal caruncles (Luo et al., 2000). In the period of two weeks before and two weeks after calving the concentration of IL-8 is lower in cows with RP, so that on the day of calving in cows without RP it was $134 \pm 11 \mathrm{pg} / \mathrm{ml}$, and in cows with RP $51 \pm 12$ $\mathrm{pg} / \mathrm{ml}$ (Kimura et al., 2002). After calving, the concentration of IL-8 is considerably higher in cows with RP than in cows without RP but all the same its level remains lower in a considerable degree.

Numerous studies confirm a stimulative effect of Se and vitamine E on the immunological status, including the activity of neutrophile granulocytes. Their antioxidative capability is manifested in the protection of non-esterified fatty acids, other cellular macromolecules and membrane against peroxidation. Bovine neutrophile granulocytes contain very little catalase, but the activity of selenoenzyme GSH-Px has an important role in protecting cytosol. Reduced function of neutrophile granulocytes is associated with a high level of superoxid $\left(\mathrm{O}^{-}\right)$. Inadequate protection against autooxidants leads to reduction of the function of neutrophyle granulocytes what may cause frequent ailments. A primary role of these nutrients is to ensure immunological defence, increase the migration of neutophile granulocytes into mammary gland where they phagocyte and destroy present bacteria (Hogan et al., 1993).

The importance of selenium and vitamin $\mathrm{E}$ in preventing the retained placenta in dairy cows. The relationship between antioxidative nutrition, oxidative stress and the incidence of retained placenta is well-known in dairy cows. Although pathogenesis of this ailment connected with Se and E vitamin deficiency is not clear enough the participation of oxidative stress in its etiology indicates a reduced incidence after selenium treatment. By adding the vitamin $\mathrm{E}$ and Se into feed, the level of this vitamin in erythrocytes, neutrophiles and plasma is increased along with the activity of enzyme GSH-Px. Besides the level of selenium in blood plasma (Todorovic et al., 1999a) the activity of glutathione peroxidase (GSH-Px) is also a 
reliable indicator of biologically adoptable selenium. Optimal and suboptimal selenium levels in feed $(0.1$ and $0.15 \mathrm{mgSe} / \mathrm{kg}$ feed $)$ result in linear increase of GSH-Px in plasma of studied individual animals. However, at certain concentrations of selenium in feed the level of GSH-Px reaches plateau so that further increase of the selenium level does not lead to the increase in the enzyme activity as well. High levels of Se (above $2 \mathrm{mgSe} / \mathrm{kg}$ feed) do not result in proportionate increase of this selenoenzyme whose activity increases at the start but fall significantly after 10th day (Joksimović Todorović and Jokić, 2005; Joksimović Todorović et al., 2005).

These nutrients reduce oxidative stress and lead to certain changes in placenta. Selenium and vitamin E possess immunomodulatory effects, in the sense of improving the function of neutrophiles, increase their migration and chemotactic activity (Gupta et al., 2005). Se deficiency affects unfavourably the function of polymorphonuclear neutrophiles and the changes in the level of GSHPx (Finch and Turner, 1996). The absence of leukocytes in placenta leads to retention of placenta in $100 \%$ cows after calving. Se and vitamin E increase the number of leukocytes in placenta, leukocyte chemotaxis, assist the abating of the links between fetomaternal juncture and ejection of placenta.

Retained placenta can be prevented by the supplement of Se and vitamin E, unless it is provoked by mechanical and pathological factors (Han and Kim, 2005; Joksimović Todorović and Davidović, 2007). Dairy cows are fed by different forms of selenium: selenate, selenite (by adding the non-organic Se in feed) and Se-met and Se-cys (Se-yiest and basal food). Numerous studies show that the adding $\mathrm{Se}$ (usually in the inorganic form) ensures immunological function, soundness of mammary gland and prenvents placenta retention. Inorganic selenium (selenit and selenat) and selenized yeast (Se-yeast) represent the sources of selenium used in bovine nutrition. Predominant form of selenium in Se-yeast is selenomethionine (Se-met). The mechanism of intestinal resorption differs in inorganic and in Semet. Factors which reduce the resorption of inorganic selenium probably do not affect the absorption of Se-met. Metabolism of inorganic and organic selenium in the cell also differ. Inorganic Se is used exclusively for the synthesis of seleno specified enzymes while Se-met can be used for the synthesis of those proteins, but it can be built into any protein which contains methionine (Weiss and Hogan, 2005). Organic selenium is less toxic than inorganic (Mihailović et al., 1996a,b, 1997), can be more rapidly stored and retained in tissues (Todorović et al., 1999b; Joksimović Todorović et al., 2006).

Besides selenium and vitamin $\mathrm{E}$ other minerals and vitamins (zink, copper, iron, vitamins $\mathrm{A}, \mathrm{C}$ and $\mathrm{E}$ ) have also been found to have important role in preventing RP. Low levels of these nutrients in dairy cows in preparturition and postparturition perioda predispose occurence of RP (Tillard et al., 2008). Insufficent content of these minerals and vitamins in food can result in abortion in 
dairy cows and as a consequence thereof in majority of cases the retained placenta is perceived.

\title{
Conclusion
}

Selenium and vitamin $\mathrm{E}$ as natural antioxidants have an important role in preventing the occurence of retained placenta. These nutrients increase the activity of neutrophiles, enhance their chemotactic effect and phagocytosis of opsonised pathogenic microorganisms. Adequately balanced rations with sufficient content of selenium, vitamin E and other antioxidants in food, appropriate housing of animals and good management lead to reducing the incidence of one of the most often ailments in dairy cows in postparturition period.

\section{Acknowledgment}

This work was financed by the Ministry of Education, Science and Technological Development, Republic of Serbia, project TR 31086: Optimisation of technological procedure and zootechnical resources on farms with the aim of improving the sustainability of milk production.

\section{Efekat antioksidanasa na sprečavanje pojave zadržavanja posteljice kod mlečnih krava}

\author{
M. Joksimović Todorović, V. Davidović
}

\section{Rezime}

Zadržavanje posteljice je jedno od najčešćih oboljenja mlečnih krava, a nastaje ukoliko se posteljica ne izbaci u periodu od 12-14h nakon teljenja. Oboljenje je multifaktorijalne etiologije, a primarni uzrok često ostaje nepoznat. U toku peripartalnog perioda kod krava dolazi do metaboličkih, hormonalnih i biohemijskih promena. Imunosupresija takođe karakteriše ovaj period, a u vezi je sa endokrinim promenama i smanjenim unosom hrane. Smanjena funkcija neutrofila pre porođaja u korelaciji je sa povećanom učestalošću nastanka postpartalnih oboljenja. Selen i vitamin E su najvažniji antioksidansi koji pozitivno utiču na funkciju neutrofila štiteći ih od oksidativnog oštećenja. 


\section{References}

BERTICS S.J., GRUMMER R.R., CADORNIGA-VALINO C., STODDARD E.E. (1992): Effect of prepartum dry matter imtake on liver tryglyceride concentration and early lactation. J. Dairy Sci., 75, 1914-1922.

BRYDL E., KÖNYVES L., TEGZES L., JURKOVICH V., TIRIAN A. (2008): Incidence of subclinical metabolic disorders in Hungarian dairy herds during the last decade. Mady Allatorv Lapja, 130, (suppl. I), 129-134.

BÜLENT E., MUSTAFA K., ÖZGÜL M.E. (2006): Evaluation of liver function tests in cows during periparturient period. Frat Üniversitesi Sal Bilimleri Dergisi (Veteriner), 20, 3, 205-209.

DE RENSIS F., SCARAMUZZI R.J. (2003): Heat stress and seasonal effects on reproduction in the dairy cow - a review. Theriogenology, 60, 1139-1151.

ELLIOTT C.L., SLATER D.M., DENNES W., POSTON L., BENNETT P.R. (2000): Interleukin-8 expression in human myometrium: Changes in relation to labor onset and with gestational age. Am. J. Reprod. Immunol., 43, 272-277.

FINCH J.M., TURNER R.J. (1996): Effects of selenium and vitamin E on the immune responses of domestic animals. Res. Vet. Sci., 60, 97-106.

GOFF J.P. (2003): Managing the transition cow-considerations for optimising energy and protein balance and immune functions. Cattle Pract., 11, 51-63.

GRUMMER R.R., MASHEK D.G., HAYIRLI A. (2004): Dry matter intake and energy balance in the transition period. Vet. Clin. NAm-Food Anim. Pract., 20, 447-470.

GUNAY A., GUNAY U., ORMAN A. (2011): Effects of retained placenta on the fertility in treated dairy cows. Bulgarian Journal of Agricultural Science, 17, 1, 126-131.

GUPTA S., HARENDRA K.G., JYOTI S. (2005): Effect of Vitamin E and selenium supplementation on concentrations of plasma cortisol and erythrocyte lipid peroxides and the incidence of retained fetal membranes in crossbred dairy cattle. Theriogenology, 64, 1273-1286.

HAN Y.K., KIM I.H. (2005): Risk factors for retained placenta and the effect of retained placenta on the occurrence of postpartum diseases and subsequent reproductive performance in dairy cows. J. Vet. Sci., 6, 53-59.

HAYIRILI A., GRUMMER R.R., NORDHEIM E.V., CRUMP P.H. (2002): Animal and dietary factors affecting feed intake during the prefresh transition period in Holsteins. J. Dairy Sci., 85, 3430-3443.

HOGAN J.S., WEISS W.P., SMITH K.L. (1993): Role of Vitamin E and Selenium in Host Defense Against Mastitis. J. Dairy Sci., 76, 2795-2803.

INGVARTSEN K.L. (2006): Feeding - and management - related diseases in the transition cow. Physiological adaptations around calving and strategies to reduce feeding - related diseases. Anim. Feed Sci. Technol., 126, 175-213. 
JOKSIMOVIĆ TODOROVIĆ M., JOKIĆ Ž. (2005): Uticaj visokih nivoa neorganskog selena na aktivnost glutation peroksidaze (GSH-Px) u krvnoj plazmi brojlera. Biotehnologija u stočarstvu, 21, 3-4, 125-131.

JOKSIMOVIĆ TODOROVIĆ M., JOKIĆ Ž., SINOVEC Z. (2005): Uticaj visokih nivoa organskog selena na aktivnost glutation peroksidaze (GSH-Px) u krvnoj plazmi brojlera. Veterinarski glasnik, 59, 3-4, 383-390.

JOKSIMOVIĆ TODOROVIĆ M., JOKIĆ Ž., HRISTOV S. (2006): The effect of different levels of organic selenium on body mass, bodyweight gain, feed conversion and selenium concentration in some gilts tissues. Acta Veterinaria, 56, 5-6, 489-495.

JOKSIMOVIĆ TODOROVIĆ M., DAVIDOVIĆ V. (2007): Selenium, oxidative stress. Proceeding of Third Symposium of Livestock Production with International Participation, Ohrid, Macedonia, 12-14. September, 527-530.

JOKSIMOVIĆ TODOROVIĆ M., DAVIDOVIĆ V. (2013): Immunosuppression postpartum diseases of dairy cows. Biotechnology in Animal Husbandry, 29, 2, 211-222.

JORRITSMA R., WENSING T., KRUIP T.A.M., VOS P.L., NOORDHUIZEN J.P.T.M. (2003): Metabolic changes in early lactation and impaired reproductive performance in dairy cows. Vet. Res., 34, 11-26.

KIMURA K., GOFF J.P., KEHRLI M.E., REINHARDT T.A. (2002): Decreased Neutrophil Function as a Cause of Retained Placenta in Dairy Cattle. J. Dairy Sci., 85, 544-550.

KORNMATITSUK B., KONIGSSON K., KINDAHL H., GUSTAFSSON H. (2000): Clinical signs, body temperature, and hormonal changes in dairy heifers after induction of parturition with PGF $2 \alpha$. 14th International Congress on Animal Reproduction, Stocholm, 1, 179.

LUO L., IBARAGI T., NOZAWA M., KASAHARA T., SAKAI M., SASAKI Y., TANEBE K., SAITO S. (2000): Interleukin-8 levels and granulocyte counts in cervical mucus during pregnancy. Am. J. Reprod. Immunool., 43, 78-84.

MARKIEWICZ H., KUMA K., MALINOWSKI E. (2001): Predisposing factors for puerperal metritis in cows. Bull. Vet. Inst. Pulawy, 45, 281-288.

MICHAL K., EDWARD M., HANNA M. (2006): Some hormonal and biochemical blood indices in cows with retained placenta and puerperal metritis. Bull. Vet. Inst. Pulawy, 50, 89-92.

MIHAILOVIĆ M., TODOROVIĆ M., JOVANOVIĆ M., PALIĆ T., JOVANOVIĆ J., PEŠUT O., KOSANOVIĆ M. (1996a): Toxicity of organic and inorganic selenium to chicken. Ninth Intrnat. Symp. of Trace Elements in Man and Animals (Tema 9) - Banff Alberta - Canada. Trace Elements in Man and Animals, 9, 554-555.

MIHAILOVIĆ M., TODOROVIĆ M., JOVANOVIĆ M., PALIĆ T., JOVANOVIĆ J., PEŠUT O., KOSANOVIĆ M. (1996b): Toxicity of sodium 
selenite and selenized yeast to chicken. The Sixt Intrnat. Symp. on selenium in Biol. and Med. - Peking NR Kina. Program and Abstract, 125.

MIHAILOVIĆ M., TODOROVIĆ M., JOVANOVIĆ M., PALIĆ T., JOVANOVIĆ J., PEŠUT O. (1997): Toxicity of selenium to broilers. XI ${ }^{\text {th }}$ International Congress of the World Poultry Association 18-22 August, Budapest, Hungary.

SEMACAN A., SEVINC M. (2005): Liver function in cows with retained placenta. Turk. J. Vet. Anim. Sci., 29, 775-778.

SHARMA N., SINGH N.K., SINGH O.P., PANDEY V., VERMA P.K. (2011): Oxidative Stress and Antioxidant Status during Transition Period in Dairy Cows. Asian-Aust. J. Anim. Sci., 24, 4, 479-484.

TILLARD E., HUMBLOT P., FAYE B., LECOMTE P., DOHOO I., BOCQUIER F. (2008): Postcalving factors affecting conception risk in Holstein dairy cowsw in tropical and sub-tropical conditions. Theriogenology, 69, 4, 443-457.

TODOROVIĆ M., MIHAILOVIĆ M., HRISTOV S. (1999a): Effects of excessive levels of sodium selenite on daily weight gain, mortality and plasma selenium concentration in chickens. Acta Veterinaria, 49, 5-6, 313-320.

TODOROVIĆ M., MIHAILOVIĆ M., HRISTOV S. (1999b): Visoki nivoi selena u ishrani pilića i njihovo deponovanje u mišićima. Savremena poljoprivreda, 1-2, 257-260.

WEISS P.W., HOGAN S.J. (2005): Effect of Selenium Source on Selenium Status, Neutrophil Function, and Response to Intramammary Endotoxin Challenge of Dairy Cows. J. Dairy Sci., 88, 4366-4374. 